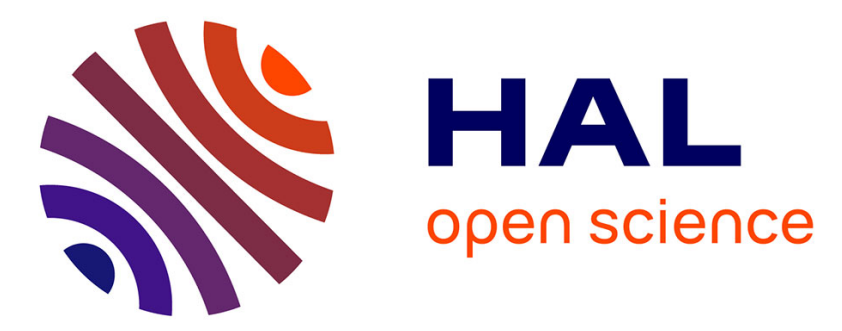

\title{
Reciprocal indirect facilitation between an invasive macrophyte and an invasive crayfish
}

Lise Thouvenot, Jacques J. Haury, Gaëtan Pottier, Gabrielle Thiébaut

\section{To cite this version:}

Lise Thouvenot, Jacques J. Haury, Gaëtan Pottier, Gabrielle Thiébaut. Reciprocal indirect facilitation between an invasive macrophyte and an invasive crayfish. Aquatic Botany, 2017, 139, pp.1-7. 10.1016/j.aquabot.2017.02.002 . hal-01483993

HAL Id: hal-01483993

https://hal-univ-rennes1.archives-ouvertes.fr/hal-01483993

Submitted on 4 Jul 2017

HAL is a multi-disciplinary open access archive for the deposit and dissemination of scientific research documents, whether they are published or not. The documents may come from teaching and research institutions in France or abroad, or from public or private research centers.
L'archive ouverte pluridisciplinaire $\mathbf{H A L}$, est destinée au dépôt et à la diffusion de documents scientifiques de niveau recherche, publiés ou non, émanant des établissements d'enseignement et de recherche français ou étrangers, des laboratoires publics ou privés. 


\section{Highlights}

We examined exotic invasive freshwater plant-herbivore interactions.

The studied invasive species were Ludwigia grandiflora and Procambarus clarkii.

Growth rate of L. grandiflora was not affect by the presence/ absence of crayfish.

Highest density of $P$. clarkii increased the fragmentation rate of $L$. grandiflora.

The number of crayfish was higher in canals invaded by L. grandiflora. 
Reciprocal indirect facilitation between an invasive macrophyte and an invasive crayfish.

Lise Thouvenot ${ }^{1,2^{*}}$, Jacques Haury ${ }^{2,3}$, Gaétan Pottier $^{4}$, Gabrielle Thiébaut ${ }^{1}$

${ }^{1}$ CNRS, UMR 6553 ECOBIO, University of Rennes 1, 35042 Rennes Cedex, France.

${ }^{2}$ INRA, UMR ESE, 35042 Rennes Cedex, France.

${ }^{3}$ Agrocampus Ouest, 35042 Rennes Cedex, France.

${ }^{4}$ INRA, U3E, 35042 Rennes Cedex, France.

*Corresponding author. Phone (+33)(0)223 236 809. Fax (+33)(0)223 235067

E-mail address: thouvenot.lise@gmail.com (L. Thouvenot)

Abstract

Exotic invasive species are one of the major threats for aquatic ecosystems. However, the interactions between exotic plants and exotic herbivores have been little studied, despite their role in invasion success. Here, we tested how interactions between an invasive plant and an invasive herbivore could affect their own growth and their colonization abilities in freshwater ecosystems. Ludwigia grandiflora and Procambarus clarkii, two exotic invasive species which co-occur in some French wetlands, were used for our laboratory experiment and field survey. Although L. grandiflora was consumed by crayfish, its growth was not significantly affected by crayfish density. Indeed, the final living biomass of $L$. grandiflora was similar to those of controls, despite significant losses induced by crayfish. Furthermore, L. grandiflora became more fragmented in the presence of a high density of $P$. clarkii, which might increase its dispersal abilities. In addition, our field survey revealed that the abundance of crayfish was higher in a patch invaded by L. grandiflora than in an uninvaded patch. Thus, the outcome of the interaction between the invasive plant and the invasive crayfish, via its positive effect on the invasion dynamics of these two species, could have dramatic consequences for native communities of freshwater ecosystems.

Keywords: abundance; colonization; crayfish; fragmentation; functional traits; herbivory; macrophytes. 


\section{Introduction}

International trade has increased the introduction rate of exotic species worldwide. In introduced areas, exotic species that became invasive (sensu Richardson et al. 2000) interact with native species through competition or predation relationships, or by changing resource availability and altering trophic interactions (Chapin et al. 1997). Several hypotheses have addressed the issue of how interactions may exacerbate or retard the invasion and spread of exotic species (e.g. "Biotic resistance hypothesis" (Elton 1958), "Invasional Meltdown Hypothesis" (Simberloff and Von Holle 1999), etc.). Terrestrial ecosystems have received a lot of attention by studies on biological invasions and on interactions between plant-plant (e.g. Cushman et al. 2011), plant-pollinator (e.g. Molina-Montenegro et al. 2008) and plant-herbivore (e.g. Wood et al. 2015). In the biological invasion context, studies on biotic interactions focus on the effect of a single exotic species, and rarely on a more complex system involving several co-occurring exotic species. Indeed, the interactions between exotic species are rarely examined (Jackson and Grey, 2013), although the outcomes of the interactions between these species are crucial for invasion success (Parker et al. 2006).

Here, we studied the interaction between an exotic invasive plant and an exotic invasive herbivore in a temperate wetland in France. The literature on the interaction between exotic invasive plants and exotic invasive herbivores in freshwater ecosystems is still scarce, even though biological invasions are numerous in aquatic ecosystems (Jackson and Grey 2013). For example, it has been shown that the impact of herbivores on plants was 5-10 times greater in aquatic ecosystems than in terrestrial ecosystems, with an average reduction of $40-48 \%$ of plant biomass by herbivores in aquatic ecosystems (Bakker et al. 2016 a; Wood et al. 2016). Furthermore, herbivore effects on plant communities vary depending on the density of herbivores and whether the species involved were native or exotic (Bakker et al. 2016 a; Wood et al. 2016); the reduction of plant abundance in communities was greater in communities with exotic herbivores than with native herbivores (Wood et al. 2016). Exotic herbivores promote the abundance of co-adapted exotic plants from the same native range, by negatively affecting native plants (Parker et al. 2006); the abundance of exotic plants was $52 \%$ higher in communities grazed by exotic herbivores than in communities grazed by native herbivores (Parker et al. 2006). Further mechanisms could be implicated in the promotion of exotic 
plant species. Exotic herbivores, via consumption, could open spaces in the native vegetation for exotic plant species, decrease the competitive abilities of native species, and reduce propagule production by native plants. Herbivores could also affect native species, via non-consumptive effects such as bioturbation, uprooting, affecting the nutrient cycle (Bakker et al. $2016 \mathrm{a}$ ), or promoting the spread and colonization abilities of exotic plant species by stem fragmentation and propagule dispersion. However, little attention has been given to the non-consumptive effects of herbivores on plants (Bakker et al. 2016 a).

In this study, the outcome of the interaction between an invasive plant and an invasive herbivore was studied with two exotic species considered as high-risk invasive species: Ludwigia grandiflora (Michaux) Greuter and Burdet subsp. hexapetala (Onagraceae) (Perennial Water Primrose) and Procambarus clarkii (Girard, 1852) (Red Swamp Crayfish). Ludwigia grandiflora is a semi-terrestrial perennial plant native from South America that has invaded many countries in Europe (Dutartre et al. 2007; Hussner 2009). Ludwigia grandiflora inhabits marshes, swamps, ponds, lakes, channels and slow-running rivers, as well as wet meadows (Lambert et al. 2010). Occupation of riverbeds by very dense mono-specific stands of $L$. grandiflora constitutes a significant threat to native plants and aquatic fauna (Lambert et al. 2010). Procambarus clarkii, which is native to south-central United States (Louisiana) and north-eastern Mexico, has been successfully introduced worldwide. Its feeding strategy is flexible (Jones et al. 2016) as crayfish are omnivores that consume large quantities of living plant tissues and plant detritus when their favoured animal prey is not available (Hobbs 1993). In the north-west of France, L. grandiflora and P. clarkii have colonized the Brière marshes (Cucherousset et al. 2006) and Lake Grand-Lieu (Struillou et al. 2006). Field observations of $L$. grandiflora consumption by P. clarkii were made in the Brière marshes (Damien et al. 2009). Crayfish induce consumptive and non-consumptive damage to macrophytes, such as scars, holes, fragmentation and by uprooting stems (Anastácio et al. 2005; Carreira et al. 2014). In general, crayfish can greatly reduce the stands of various macrophytes (Gherardi 2007). For example, crayfish affect the abundance of Cladophora glomerata (Creed 1994) and Potamogeton pectinatus (Feminella and Resh 1989), and the seedling emergence and establishment of Najas oguraensis and Potamogeton pectinatus (Shinichiro et al. 2009). Furthermore, Gherardi and Acquistapace (2007) found that low or high densities of 
P. clarkii via grazing and non-consumptive plant clipping and uprooting, led to the disappearance of Nymphoides peltata, Potamogeton filiformis and Potamogeton crispus.

Thus, we studied the growth and fragmentation of $L$. grandiflora in the presence of different densities of $P$. clarkii and observed whether in turn L. grandiflora affected P. clarkii abundance. Here, stem fragmentation by crayfish is considered as a positive effect that could promote the spread and colonization abilities of the plant species via the formation and dispersion of propagules.

Consequently, this study could allow us to determine whether these two invasive species are able to facilitate each other's growth, spread and colonization in invaded ecosystems. An indirect reciprocal facilitation of $P$. clarkii on L. grandiflora could be important in the colonization of new habitats and in the maintenance of their populations in ecosystems. We addressed this issue by using a mixed approach of a laboratory experiment and a field survey.

2. Materials and methods

\subsection{Laboratory experiment}

The study was carried out in a glasshouse in September 2011. Ludwigia grandiflora was collected in ponds called Apigné ( $48^{\circ} 05^{\prime} 41.4^{\prime \prime}$ N, $01^{\circ} 44^{\prime} 25.2^{\prime \prime}$ W) in Brittany (France), where no crayfish species had been recorded. Individuals collected were without apparent damage from grazers. After collection, plants were washed carefully with tap water to remove epiphytes and invertebrates and stored in containers with tap water for one week at the glasshouse temperature prior to the experiment. Individuals of $P$. clarkii were collected in the Brière marshes $\left(47^{\circ} 23^{\prime} 39.5^{\prime \prime} \mathrm{N}, 02^{\circ} 18^{\prime}\right.$ 53.3" W) in Brittany, France. Only adult males with a cephalothorax dorsal mid-line (CTL: from the tip of the rostrum to the carapace posterior portion) of about $40 \mathrm{~mm}$, and lengths ranging from 6.0 to $9.9 \mathrm{~cm}$ (Mean \pm SE: $8.88 \pm 1.3 \mathrm{~cm}$ ) were selected to avoid sexual and maturity biases. Crayfish were starved in tap water for one week at the glasshouse temperature prior to the experiment.

14 enclosed containers were set up in the glasshouse exposed to natural light. Each container was divided into 3 experimental units (EU) with an opaque plastic barrier that was impermeable to water $(L \times W \times H: 33 \mathrm{~cm} \times 40 \mathrm{~cm} \times 35 \mathrm{~cm})$ in order to isolate each crayfish treatment. Three crayfish treatments were investigated: control (without crayfish); one crayfish, and three crayfish. Densities 
were in the range of natural field densities recorded in invaded areas (e.g. around 3.8 ind. $\mathrm{m}^{-2}$ in a Spanish floodplain wetland (Angeler et al. 2001); 14 ind. $\mathrm{m}^{-2}$ in a Mediterranean Wetland (Scalici and Gherardi 2007)). Each crayfish was randomly assigned to a treatment, and each treatment was randomly assigned to an EU. One main stem with ten erect secondary shoots of L. grandiflora was planted in $5 \mathrm{~cm}$ of sand in each EU filled to a depth of $8 \mathrm{~cm}$ of tap water (except for two experimental units that contained 9 secondary shoots instead of 10). The main stem was inserted below the sand and consequently was not accessible to crayfish while the secondary shoots were above the sand.

There were 14 replicates per treatment. In the glasshouse, the temperature was measured every half minute with a sensor (HOBO TidbiT Water Temperature Data Logger) (Temperature (Means \pm $\left.\mathrm{SE}): 16.98 \pm 0.27^{\circ} \mathrm{C}\right)$. Chemical composition of the water was analysed before the experiment using spectrophotometric techniques (WTW kit and Photolab S12) (Means $\pm \mathrm{SE}:\left[\mathrm{NO}_{2}{ }^{-}\right]=0.15 \pm 0.02 \mathrm{mg} / \mathrm{L}$; $\left.\left[\mathrm{NO}_{3}{ }^{-}\right]=34.65 \pm 2.13 \mathrm{mg} / \mathrm{L} ;\left[\mathrm{NH}_{4}{ }^{+}\right]=0.08 \pm 0.008 \mathrm{mg} / \mathrm{L} ;\left[\mathrm{PO}_{4}{ }^{3-}\right]=0.02 \pm 0.006 \mathrm{mg} / \mathrm{L}\right)$. The experiment was a short term experiment (4 days) in order to make comparisons with the literature (Cronin et al, 2002 ; Anastácio et al 2005; Carreira et al 2014) and because the biomass of the invasive plant L. grandiflora can double between 11 and 17 days under controlled conditions (Dutartre et al., 2005). During the 4-day experiment, the water levels in the aquaria were maintained constant.

At the end of the experiment, crayfish had both consumed and destroyed plants. To characterize the effect of crayfish on L. grandiflora, several traits were studied. We measured the number of cut shoots and the free leaf biomass found floating in the water column or floating at the water surface in the aquaria. The cut shoots corresponded to floating fragments cut by crayfish. The free leaf biomass corresponded only to the leaves cut by the crayfish (cut shoots were not included in the measure of the free leaf biomass). We also characterized the effect of crayfish on the reproductive and dispersal capacities of the plant using the measurements of the percentage of apices and the percentage of damaged leaves on the plant (which corresponded to leaves with damage like scars or holes), as well as the change in the mean number of buds per shoot. We used the word "apex" for the apical meristem in order to quantify the effect of crayfish on apical growth of each shoot of the plant, while we used the word "bud" (size inferior to $0.5 \mathrm{~mm}$ ) for the lateral buds located at the leaf nodes. The change in the mean number of buds per shoot was calculated as: [(mean number of buds at the end of the 
experiment) - (mean number of buds at the beginning of the experiment)]. Then, we calculated the partial relative growth rate of plant $\left(\mathrm{pRGR} ; \mathrm{d}^{-1}\right)$. As biomass data for cut shoots were not available, the pRGR is derived from the fresh biomass of the living (remaining) plant (= the fresh biomass of the main stem with the erect secondary shoots and the free leaf biomass). Our formula was based on the one of Hunt (1990): $p R G R=(\ln (B 2)-\ln (B 1)) /(T 2-T 1)$, where $B 1$ and $B 2$ refer to fresh biomass, at times $T 1$ and $T 2$ respectively. We assumed that the plant response to crayfish damage could be either 1) an overcompensation (i.e. significant increase of $\mathrm{pRGR}$ ), 2) a compensation (i.e. no significant effect on pRGR), or 3) the absence of compensation (i.e. a significant decrease of pRGR).

\subsection{Field survey: assessment of crayfish abundance.}

The field study was carried out in the Nézyl marsh, which is located inside the Brière marsh, and represents about 7000 ha of freshwater marsh located in the estuary of the Loire River in the north-west of France $\left(47^{\circ} 22^{\prime} \mathrm{N}, 02^{\circ} 11^{\prime} \mathrm{W}\right)$. The Brière marsh is composed of a network of permanently flooded channels within a patchwork of temporary habitats including grazed grasslands, reed beds and water ponds (Cucherousset et al. 2006). The rainfall regime and water level regulations inundate the different habitats seasonally, whereas channels are permanently flooded. L. grandiflora and P. clarkii were respectively introduced into the Brière marsh in 1994 and 1988 and have progressively colonized different habitats in Brière (Haury and Damien, 2012). In the Nézyl marsh, when crayfish had not eliminated any native vegetation, the plant communities uninvaded by $L$. grandiflora were dominated by emergent species such as Phalaris arundinacea, Iris pseudacorus, Sparganium erectum, Carex elata, Juncus effusus. Some patches of aquatic plants were present (Lemna minor, Ranunculus spp., and Callitriche brutia, C. obtusangula, C. stagnalis).

In this experiment, carried out in July 2013, we evaluated the number of crayfish (using the catch-per-unit-effort (CPUE, individuals.trap $\left.{ }^{-1} .24 \mathrm{~h}^{-1}\right)$ ) in the presence and absence of L. grandiflora stands in the Nézyl marsh. 48 cylindrical traps, with a side entrance $(L \times W \times H: 50 \mathrm{~cm} \times 30 \mathrm{~cm} \times 25$ $\mathrm{cm})$, were placed randomly, at least 2 meters apart in two patches (24 traps per patch) within the studied channel. One patch was devoid of L. grandiflora or other plant species, and the other patch, at a distance of about $30 \mathrm{~m}$, was invaded by L. grandiflora. The sex of crayfish was determined and the 
cephalothorax length (CTL) of each crayfish was measured in order to evaluate its maturity (Juvenile: $\mathrm{CTL} \leq 3.2 \mathrm{~cm}$; Immature: $3.2<\mathrm{CTL} \leq 4 \mathrm{~cm}$ and Adult: $4 \mathrm{~cm}<\mathrm{CTL}$; Bhattacharya 1967).

\subsection{Statistical analysis}

Statistical tests were performed using statistical RTM 2.13.0 software. The effect of herbivore density in the laboratory experiment was tested on the morphological traits of the plant species with a one way ANOVA and Generalized Linear Models. ANOVA was performed for the pRGR. Normality of the distribution of residuals for pRGR was checked by Q-Q plot ("plot" function of the package "base"). Tukey's HSD test was applied to observe differences between treatments. An a posteriori power analysis was performed for pRGR using the " $p w r$.anova.test" function in the package " $p w r$ " (Champely 2016) in R software. Model distributions for Generalized Linear Models were determined using histograms of the data of each trait. For the number of cut shoots, the percentage of damaged leaves, the number of apices and the free leaf biomass, we fitted models with a Poisson distribution and a $\log$ link. A Gaussian distribution was used for the number of buds. When appropriate, we carried out a post-hoc test: multiple comparisons of means (Tukey Contrasts) were performed using " $g l h t$ " function of the package "multcomp" (Bretz et al. 2010).

In the field experiment, we analysed the catch-per-unit-effort (CPUE) (logarithm transformation) as a function of the presence of L. grandiflora, as well as the sex and the maturity stage of $P$. clarkii, with a three way ANOVA. Adequate normality of the distribution of residuals was checked for each variable by Q-Q plots and Shapiro-Wilk tests. Tukey's HSD tests were applied to observe differences between treatments. Untransformed means and standard errors are given to facilitate interpretation.

\section{Results}

The glasshouse experiment showed that the partial relative growth rate (pRGR, Fig. 1a, Tab. 1) of $L$. grandiflora was not significantly affected by crayfish density $(\mathrm{Df}=2, \mathrm{~F}=0.39, \mathrm{p}=0.68)$. The presence of crayfish increased the free leaf biomass of L. grandiflora $\left(\mathrm{Df}=2, \chi^{2}=6.02, \mathrm{p}<0.05\right.$, Fig. $1 \mathrm{~b}$, Tab.1 $)$. The mean number of buds per stem tended to be higher in the absence of crayfish (mean \pm SE: $0.23 \pm 0.13$ ) than in the presence of three crayfish (mean $\pm S E:-0.14 \pm 0.14)(D f=2, F=2.78, p<0.10$, Fig. 1c). The 
apices of $L$. grandiflora were significantly affected by the density of three crayfish: we observed a decrease of about $15 \%$ of the number of apices of shoots at the highest density ( $\mathrm{Df}=2, \chi^{2}=0.171$, $\mathrm{p}<0.001$, Fig. 1d). We found that the percentage of damaged L. grandiflora leaves increased significantly by about $15 \%$ with one crayfish and doubled (32\%) with three crayfish $\left(\mathrm{Df}=2, \chi^{2}=609.77\right.$, $\mathrm{p}<0.0001$, Fig. 1e). At the highest density of crayfish, the number of cut shoots increased significantly $\left(\mathrm{Df}=2, \chi^{2}=22.19, \mathrm{p}<0.0001\right.$, Fig. 1f, Tab. 1).

The field survey suggested that the number of crayfish trapped was higher in the patch of $L$. grandiflora than in the uninvaded patch $(\mathrm{Df}=1, \mathrm{~F}=74.03, \mathrm{p}<0.0001$, Fig.2a, Tab. 2$)$ and that trapped crayfish were mostly adult and immature individuals $(\mathrm{Df}=2, \mathrm{~F}=5.67, \mathrm{p}=0.004, \mathrm{Tab} .2)$. However, the trapped crayfish did not vary with the sex of the individual (Tab.1). There was a significant interaction between the "presence of $L$. grandiflora - maturity stage of crayfish" $(\mathrm{Df}=2, \mathrm{~F}=7.10, \mathrm{p}<0.0001$, Fig.2b, Tab. 2): Adult, immature and juvenile crayfish were more abundant in the patch of $L$. grandiflora, than juvenile and adult crayfish in the absence of $L$. grandiflora (Fig. $2 \mathrm{~b}$ ).

\section{Discussion}

We did not find a significant effect of the invasive species $P$. clarkii on the growth of the invasive $L$. grandiflora. Surprisingly, despite different types of damage and the consumption by $P$. clarkii, the growth rate of L. grandiflora was not significantly different between crayfish treatments. This result is contradictory to those found by many authors who have reported a reduction of other macrophyte biomass caused by crayfish (Feminella and Resh 1989; Sánchez and Angeler 2006) as a result of both consumption and plant fragmentation (Gherardi and Acquistapace 2007, Carreira et al. 2014). Wood et al. (2016) showed that plant abundance was reduced at high herbivore density, but that a positive change in plant abundance occurred at low herbivore density. Thus, Wood et al. (2016) suggested that plant compensatory growth responses were not high enough to compensate for the loss of biomass at high herbivore density (Wood et al. 2016). Here, we observed that L. grandiflora compensated for the loss of biomass due to crayfish predation. Indeed, the final living biomass of $L$. grandiflora was similar to those of controls despite significant losses induced by crayfish. Furthermore, the biomass of cut shoot parts was not taken into account in the calculation of the 
relative growth rate, which is consequently underestimated. As the number of cut shoots increased with crayfish density, considering their biomass in our analysis would reinforce our result i) of an absence of a negative effect of crayfish density on the growth of $L$. grandiflora and ii) of the compensatory growth responses of L. grandiflora. However, the large intragroup variability of pRGR values could have led to the non-detection of a significant difference between the pRGR of the three crayfish treatments. Indeed, the a posteriori power analysis revealed a low power for the statistical analysis $($ Statistical power $=0.0627)$ explained by a high variance within groups and a low effect size . For our resulting effect size (0.019), we would have needed more than 8000 replicates to obtain a significant effect (0.5) with a correct power (0.8). Thus, one limitation of our results on pRGR may be related to the large intragroup variability of pRGR values, even if our number of replicates (14) was equivalent (Anastácio et al. 2005; Carreira et al. 2014) or larger than (Creed 1994; Sánchez and Angeler 2006; Gherardi and Acquistapace 2007) that usually used for these laboratory experiments.

Among the different types of damage to L. grandiflora, we showed that $P$. clarkii consumed apices, buds of the stems, and leaves which may compromise the growth of the plant. Furthermore, high densities of crayfish can destroy tissues and induce an increase of the quantity of free biomass and shoot fragments of $L$. grandiflora. This crayfish behaviour, by destroying more tissues than they consume (Lodge 1991), makes biomass more easily handled (Cronin et al. 2002). Thus, crayfish could benefit of the availability of the free biomass, which could have highly nutritive values due to microbial conditioning or leaching of the chemical defences (Newman 1991). Moreover, the free cut shoot could have different decomposition rates and be reused by crayfish as nutritious coarse particulate organic matter (Vannote et al. 1980; Anastácio et al. 2005). Our results, showing an increasing number of shoot fragments with crayfish predation, are coherent with the literature (Anastácio et al. 2005, Carreira et al. 2014). For example, Carreira et al (2014) found that crayfish size affected the number of fragments produced, which was around $1.6 \pm 0.1$ to $9.5 \pm 1.1$ fragments.day $^{-1}$, depending on the macrophytes species. Fragmentation under laboratory conditions maybe underestimated in comparison to pond conditions (Carreira et al., 2014): the greater water depth and the higher plant density could favour the fragments cut by crayfish. Although the cut fragments of $L$. grandiflora could be consumed or reused by crayfish, they could also promote its dispersal and 
propagation. Most macrophytes can regenerate new plants from their fragments and so fragmentation is very important for plant propagation, dispersal and maintenance of the plant population (BarratSegretain et al. 1999). After an 8-week experiment, Hussner (2009) found that L. grandiflora showed a high potential for regeneration from small shoot fragments $(1 \mathrm{~cm})$ with nodes, with or without leaves, and to a lesser extent from single leaves. Fragments of $L$. grandiflora are buoyant and can easily float away from parent plants and regenerate readily (Dandelot 2004), even if their anchorage rate depends on the composition of the macrophyte bed (Thiébaut and Martinez, 2015). Thus, the propagation and colonization abilities of the invasive L. grandiflora, as well as its abundance in invaded ecosystems, could indirectly benefit from the presence of the invasive $P$. clarkii. Native and exotic herbivores have opposing effects on the relative abundance of exotic plants, with an increase of the abundance of exotic plants by exotic herbivores (Parker et al. 2006). For example, Maezo et al. (2010) found a positive effect of rusty crayfish (Orconectes rusticus) on the propagation of the invasive Eurasian watermilfoil (Myriophyllum spicatum) in a mesocosm experiment. However, these two species did not co-occur in the field (Maezo et al. 2010). Further experiments are required to confirm that P. clarkii may have a positive effect on the dispersal of L. grandiflora in the field. Indeed, the viability and the buoyancy of shoot fragments could be affected by herbivore damage. For example, Creed and Sheldon (1995) have shown that the viability and the buoyancy of damaged stem fragments of Myriophyllum spicatum were reduced compared to undamaged stem fragments. Consequently, it is crucial to know the survival rate of the shoot fragments, the chances of these fragments to be rooted in the substratum in the presence and absence of crayfish, their regeneration abilities and to investigate whether the growth, recruitment and colonization of the fragmented stems are faster than crayfish consumption.

Damage and consumption by herbivores are dependent on the composition of macrophyte communities. Thus, the presence of macrophyte species preferred by crayfish could reduce the impact on some other macrophytes species (Carreira et al. 2014), although crayfish may fragment all of the macrophyte species in order to find the most palatable species (Carreira et al. 2014). In natura, L. grandiflora often builds up monospecific mats and outcompetes other aquatic and emergent species in wetlands (Dutartre et al. 2007; Stiers et al. 2011). The vegetation structure influences the ability of crayfish to establish in an area (Cruz and Rebelo 2007) and our field survey suggests that the patch of 
L. grandiflora is interesting for crayfish establishment. Indeed, a stand of L. grandiflora hosts a higher abundance of crayfish, regardless of maturity stage and so L. grandiflora patches may play a role in the development, life cycle and/or in the colonization abilities of $P$. clarkii. High plant biomass could provide a safer refuge, reducing the ability of predators to detect and capture their prey (Jordan et al. 1996), and could supply food and energy to crayfish in anticipation of the breeding season or to replenish energy channelled towards reproduction (Gherardi 2007; Carreira et al. 2014). However, the conclusions from our field survey should be considered with caution, since the results are from a single channel and consequently suffer from pseudoreplication. These initial field observations should be extended to other channels (channels with native plants, invaded or not by L. grandiflora and $P$ clarkii), and to wet meadows where P. clarkii and L. grandiflora are becoming invasive (Haury et al. 2014 ) in order to draw some general conclusions. Similarly, the long term impact of $P$. clarkii on $L$. grandiflora and its impact during the life cycle of L. grandiflora could be studied. Furthermore, it would be interesting to test the impact of other animals such as coypu or grass carp, as the consumption and fragmentation of plant species mainly depends on the animal species and the body size of herbivores or omnivores. Indeed, omnivores and some strict herbivores mainly consume macrophytes (Bakker et al. 2016 a) and herbivores such as grass carp have the strongest impact on submerged plant abundance and the composition of aquatic plant communities (Bakker et al. $2016 \mathrm{~b}$ ). Herbivores and omnivores often feed on both aboveground and belowground plant material (Bakker et al. 2016 a), which may increase the damage to plants and plant communities, especially when the herbivore has restricted mobility and bulk grazing strategies (Wood et al. 2016).

The two species of our study could benefit from each other's presence. Procambarus clarkii could contribute to the colonization abilities of Ludwigia grandiflora by enhancing its fragmentation, and L. grandiflora could favour the colonization of ecosystems by $P$. clarkii because of its dense mats which provide a refuge to all maturity stage of crayfish against predators. The outcome of the relationship between the invasive $L$. grandiflora and $P$. clarkii must be clarified with other experiments because of the considerable implications for their future distributions and for freshwaters conservation. This suggests that in a case of indirect reciprocal facilitation, a simultaneous action of eradication might be necessary to mitigate the invasion of both species. In the worst case scenario, the 
indirect reciprocal facilitation which may occur between these two species in the case of overlapping distribution, could lead to an increase of their growth, spread and geographical distribution area, and potentially to an “Invasional Meltdown" (Von Holle and Simberloff 1999), increasing the threats to native communities and ecosystems.

\section{Acknowledgements}

We thank the staff of the Unité Expérimentale d'Ecologie et d'Écotoxicologie aquatique (Institut National de la Recherche Agronomique, Rennes, France) including Didier Azam, Martine Ollitrault, Alphonse Quéméneur, Maïra Coke, Antoine Gallard, Bernard Joseph, Cédric Lacoste and Julien Tremblay for preparing the experimental design and for their assistance during the experiments. We also thank Jean-Patrice Damien (Parc Naturel Régional de Brière), Anne Tréguier for help in the field and for providing advice on P. clarkii. We are grateful to Benoit Gauzens for his useful comments on the manuscript. We also thank the Editor-in-Chief and the two reviewers for their helpful remarks and corrections of a previous manuscript. Grants for the field study were provided by ONEMA, DREAL Pays de la Loire, and technical facilities were given by PNR Brière.

\section{Authors' contributions}

The study was carried out in collaboration with all the authors. GT and JH initiated the research project. LT and GT defined the research questions and designed the laboratory experiments. JH and GP designed the field experiments. LT and GP performed the experiment. LT analysed the data, interpreted the results and wrote the manuscript. All authors have contributed to and approved the manuscript. 


\section{References}

Anastácio, P.M., Parente, V.S., Correia, A.M., 2005. Crayfish effects on seeds and seedlings: identification and quantification of damage. Freshwater Biol. 50, 697-704.

Angeler, D.G., Sánchez-Carrillo, S., García, G., Alvarez-Cobelas, M., 2001. The influence of Procambarus clarkii (Cambaridae, Decapoda) on water quality and sediment characteristics in a Spanish floodplain wetland. Hydrobiologia 464, 89-98.

Barrat-Segretain, M.H., Henry, C.P., Bornette, G., 1999. Regeneration and colonization of aquatic plant fragments in relation to the disturbance frequency of their habitats. Arch. Hydrobiol. 145, 111127.

Bhattacharya, C., 1967. A simple method of resolution of a distribution into Gaussian components. Biometrics 115-135.

Bakker, E. S., Wood, K. A., Pagès, J. F., Veen, G. C., Christianen, M. J., Santamaría, L., Nolet, B.A., Hilt, S., 2016 a. Herbivory on freshwater and marine macrophytes: A review and perspective. Aquat. Bot. $135,18-36$.

Bakker, E. S., Arthur, R., Alcoverro, T., 2016 b. Assessing the role of large herbivores in the structuring and functioning of freshwater and marine angiosperm ecosystems. Ecography 39, 162-179.

Bretz, F., Hothorn, T., Westfall, P., 2010. Multiple comparisons using R. Boca Raton, FL: CRC Press. $205 \mathrm{p}$.

Carreira, B. M., Dias, M. P., Rebelo, R., 2014. How consumption and fragmentation of macrophytes by the invasive crayfish Procambarus clarkii shape the macrophyte communities of temporary ponds. Hydrobiologia 721, 89-98.

Champely, S., 2016. PWR: Basic functions for power analysis. 
Chapin, F.S., Walker, B.H., Hobbs, R.J., Hooper, D.U., Lawton, J.H., Sala, O.E., Tilman, D., 1997.

Biotic control over the functioning of ecosystems. Science 277, 500-504.

Creed, R.P., 1994. Direct and indirect effects of crayfish grazing in a stream community. Ecology 75 , 2091-2103.

Creed, R. P., Sheldon, S. P., 1995. Weevils and watermilfoil: Did a North American herbivore cause the decline of an exotic plant? Ecol. Appl. 5, 1113-1121.

Cronin, G., Lodge, D.M., Hay, M.E., Miller, M., Hill, A.M., Horvath, T., Bolser, R.C., Lindquist, N., Wahl, M., 2002. Crayfish feeding preferences for fresh water macrophytes: The influence of plant structure and chemistry. J. Crustacean Biol. 22, 708-718.

Cruz, M.J., Rebelo, R., 2007. Colonization of freshwater habitats by an introduced crayfish, Procambarus clarkii, in Southwest Iberian Peninsula. Hydrobiologia 575, 191-201.

Cucherousset, J., Paillisson, J.M., Carpentier, A., Eybert, M.C., Olden, J., 2006. Habitat use of an artificial wetland by the invasive catfish Ameiurus melas. Ecol. Freshw. Fish. 15, 589-596.

Cushman, J.H., Lortie, C.J., Christian, C.E., 2011. Native herbivores and plant facilitation mediate the performance and distribution of an invasive exotic grass. J. Ecol. 99, 524-531.

Damien, J.P., Le Grill, T., Bernard, J.Y., Haury, J., 2009, Invasive macrophytes and trophic webs in natural regional park of Briere (Western France). ASLO Aquatic Science Meeting.

Dandelot, S., 2004, Les Ludwigia spp invasives du sud de la France : historique, biosystématique, biologie et écologie. Faculté des Sciences et Techniques de Saint-Jérôme. Université Paul Cézanne Aix Marseille, p. 213.

Dutartre, A., Bertrin, V., Laplace-Treyture, C., 2005. Suivi scientifique et technique des jussies (Ludwigia spp.): programme 2004. Evaluation des biomasses produites, anse Sud Est de l'étang de Léon. p. 15. 
Dutartre, A., Haury, J., Dandelot, S., Coudreuse, J., Ruaux, B., Lambert, E., Le Goffe, P., Menozzi, M.J., 2007. Les jussies: caractérisation des relations entre sites, populations et activités humaines. Implications pour la gestion. Programme de recherche "Invasions Biologiques" 2003-2006, 128 pp.

Elton, C., 1958. The ecology of invasions by animals and plants. Methuen, London.

Feminella, J.W., Resh, V.H., 1989. Submersed macrophytes and grazing crayfish - an experimentalstudy of herbivory in a California fresh-water marsh. Holarctic Ecol. 12, 1-8.

Gherardi, F., 2007. Understanding the impact of invasive crayfish. Biological invaders in inland waters: Profiles, distribution, and threats. Springer, pp. 507-542.

Gherardi, F., Acquistapace, P., 2007. Invasive crayfish in Europe: the impact of Procambarus clarkii on the littoral community of a Mediterranean lake. Freshwater Biol. 52, 1249-1259.

Haury, J., Damien, J.-P., 2012. Les invasions biologiques dans le Parc naturel régional de Brière : présentation d'une recherche-action. Sciences Eaux et Territoires n ${ }^{\circ}$ spécial Invasions biologiques 062012, 26-33.

Haury, J., Druel, A., Cabral, T., Paulet, Y., Bozec, M., Coudreuse, J., 2014. Which adaptations of some invasive Ludwigia spp.(Rosidae, Onagraceae) populations occur in contrasting hydrological conditions in Western France?. Hydrobiologia 737, 45-56.

Hobbs, H.H., 1993. Cambarus (jugicambarus) subterraneus, a new cave crayfish (decapoda, cambaridae) from northeastern Oklahoma, with a key to the troglobitic members of the subgenus jugicambarus. P. Biol. Soc. Wash. 106, 719-727.

Hunt, R., 1990, Basic growth analysis. Unwin Hyman, London, UK.

Hussner, A., 2009. Growth and photosynthesis of four invasive aquatic plant species in Europe. Weed Res. 49, 506-515. 
Jackson, M. C., Grey, J., 2013. Accelerating rates of freshwater invasions in the catchment of the River Thames. Biol. Invasions 15, 945-951.

Jones, E.W., Jackson, M.C., Grey J., 2016. Environmental Drivers for Population Success: Population Biology, Population and Community Dynamics. In Biology and Ecology of Crayfish, Edited by Matt Longshaw and Paul Stebbing, CRC Press 2016. Pages 251-286

Jordan, F., DeLeon, C.J., McCreary, A.C., 1996. Predation, habitat complexity, and distribution of the crayfish Procambarus alleni within a wetland habitat mosaic. Wetlands 16, 452-457.

Lambert, E., Dutartre, A., Coudreuse, J., Haury, J., 2010. Relationships between the biomas production of invasive Ludwigia species and physical properties of habitats in France. Hydrobiologia $656,173-186$

Lodge, D.M., 1991. Herbivory on freshwater macrophytes. Aquat. Bot. 41, 195-224.

Maezo, M.J., Fournier, H., Beisner, B.E., 2010. Potential and realized interactions between two aquatic invasive species: Eurasian watermilfoil (Myriophyllum spicatum) and rusty crayfish (Orconectes rusticus). Can. J. Fish. Aquat. Sci. 67, 684-700.

Shin-ichiro S.M., Usio, N., Takamura, N., Washitani, I., 2009. Contrasting impacts of invasive engineers on freshwater ecosystems: an experiment and meta-analysis. Oecologia 158, 673-686.

Molina-Montenegro, M.A., Badano, E.I., Cavieres, L.A., 2008. Positive interactions among plant species for pollinator service: assessing the 'magnet species' concept with invasive species. Oikos 117, 1833-1839.

Newman, R.M., 1991. Herbivory and Detritivory on Freshwater Macrophytes by Invertebrates: A Review. J. N. Am. Benthol. Soc. 10, 89-114.

Parker, J. D., Burkepile, D. E., Hay, M. E., 2006. Opposing effects of native and exotic herbivores on plant invasions. Science 311, 1459-1461. 
Richardson, D. M., Pyšek, P., Rejmánek, M., Barbour, M. G., Panetta, F. D., West, C. J., 2000.

Naturalization and invasion of alien plants: concepts and definitions. Diver. Distrib. 6, 93-107.

Scalici, M., Gherardi, F., 2007. Structure and dynamics of an invasive population of the red swamp crayfish (Procambarus clarkii) in a Mediterranean wetland. Hydrobiologia 583, 309-319.

Simberloff, D., Von Holle, B., 1999. Positive interactions of nonindigenous species: invasional meltdown? Biol. Invasions 1, 21-32

Stiers, I., Crohain, N., Josens, G., Triest, L., 2011. Impact of three aquatic invasive species on native plants and macroinvertebrates in temperate ponds. Biol. Invasions 13, 2715-2726.

Strauss, S. Y., Agrawal, A. A., 1999. The ecology and evolution of plant tolerance to herbivory. Trends Ecol. Evol. 14, 179-185.

Struillou, J.F., Ménanteau, L., Chadenas, C., Pourinet, L., 2006, Protection du patrimoine naturel et développement durable dans la région de la basse-Loire. Le cas du lac de Grand-Lieu. Interaction Nature-Société, analyse de modèles, p. 7.

Sánchez, I.A., Angeler, D.G., 2006. A conceptual model of exotic crayfish (Procambarus clarkii) effects on charophyte propagule banks in wetlands. Revista Latinoamericana de Recursos Naturales 2, $17-23$.

Thiébaut, G., Martinez, L., 2015. An exotic macrophyte bed may facilitate the anchorage of exotic propagules during the first stage of invasion. Hydrobiologia, 746, 183-196.

Vannote, R.L., Minshall, G.W., Cummins, K.W., Sedell, J.R., Cushing, C.E., 1980. The river continuum concept. Can. J. Fish. Aquat. Sci. 37, 130-137.

Wood, J.R., Dickie, I.A., Moeller, H.V., Peltzer, D.A., Bonner, K.I., Rattray, G., Wilmshurst, J.M., 2015. Novel interactions between non-native mammals and fungi facilitate establishment of invasive pines. J. Ecol. 103, 121-129. 
Wood, K. A., O'Hare, M. T., McDonald, C., Searle, K. R., Daunt, F., Stillman, R. A., 2016. Herbivore regulation of plant abundance in aquatic ecosystems. Biol. Rev. http://dx.doi.org/10.1111/brv.12272. 


\section{TABLES}

Table 1. Mean ( \pm SD) of plant biomass, Free leaf biomass, partial Relative Growth Rate and Number of cut shoots, depending on the crayfish treatment. Statistical differences (Tukey's test, $p<0.05$ ) are indicated: different small letters above columns indicate significant differences between crayfish density (ns: no significant difference between the treatments)

\begin{tabular}{c|cccccc}
\hline $\begin{array}{c}\text { Crayfish } \\
\text { treatment }\end{array}$ & $\begin{array}{c}\text { Biomass of } \\
\text { plant at the } \\
\text { beginning of } \\
\text { the experiment }\end{array}$ & $\begin{array}{c}\text { Biomass of the } \\
\text { intact plant }(\mathrm{g}) \\
\text { at the end of the } \\
\text { experiment }\end{array}$ & $\begin{array}{c}\text { Free leaf } \\
\text { biomass }(\mathrm{g})\end{array}$ & $\begin{array}{c}\text { pRGR of plant } \\
\text { (including free } \\
\text { leaf biomass) } \\
\left(\mathrm{d}^{-1}\right)\end{array}$ & $\begin{array}{c}\text { RGR of the } \\
\text { intact plant } \\
\text { (without free } \\
\text { leaf biomass } \\
\text { and cut } \\
\text { shoots) }\left(\mathrm{d}^{-1}\right)\end{array}$ & $\begin{array}{c}\text { Number of cut } \\
\text { shoots }\end{array}$ \\
\hline Control & $32.39 \pm 2.82$ & $35.81 \pm 3.20$ & $0.509 \pm 0.092^{\mathrm{b}}$ & $0.029 \pm 0.003^{\mathrm{ns}}$ & $0.025 \pm 0.003$ & $0.000 \pm 0.000^{\mathrm{b}}$ \\
One crayfish & $26.64 \pm 2.77$ & $27.96 \pm 2.80$ & $0.848 \pm 0.279^{\mathrm{ab}}$ & $0.022 \pm 0.008^{\mathrm{ns}}$ & $0.015 \pm 0.009$ & $0.286 \pm 0.170^{\mathrm{ab}}$ \\
& $27.54 \pm 1.92$ & $28.64 \pm 2.03$ & $1.387 \pm 0.339^{\mathrm{a}}$ & $0.023 \pm 0.006^{\mathrm{ns}}$ & $0.010 \pm 0.007$ & $1.071 \pm 0.368^{\mathrm{a}}$ \\
\hline
\end{tabular}


Table 2. Summary of the three way ANOVA (with $F$ and $p$-values for each factor) on the number of trapped crayfish as a function of the presence or absence of $L$. grandiflora, the sex and maturity stage of $P$. clarkii, as well as the interaction between these factors. Significant results are in bold type.

\begin{tabular}{lccc}
\hline \multicolumn{1}{c}{ Types of effect } & Df & $F$ & $p$ \\
\hline Presence of L. grandiflora & 1 & 74.03 & $<\mathbf{0 . 0 0 0 1}$ \\
Sex & 1 & 0.11 & 0.73 \\
Maturity stage & 2 & 5.67 & $\mathbf{0 . 0 0 4}$ \\
Presence x Sex & 1 & 0.14 & 0.70 \\
Presence x Maturity & 2 & 7.10 & $<\mathbf{0 . 0 0 0 1}$ \\
Sex x Maturity & 2 & 0.31 & 0.73 \\
Presence x Maturity x Sex & 2 & 0.06 & 0.94 \\
\hline
\end{tabular}




\section{FIGURE CAPTIONS}

Fig. 1 Impact of crayfish density (mean $\pm \mathrm{SE}, \mathrm{n}=14$ ) on the partial Relative Growth Rate $(\mathrm{GR}, 1 \mathrm{a})$, on the free leaf biomass (1b), on the change in the mean number of buds per shoot (1c), the presence of apices (1d), the percentage of damaged leaves (1e) and on the mean number of cut shoots (1f) of $L$. grandiflora. Statistical differences (Tukey's test, $\mathrm{p}<0.05$ ) are indicated: different small letters above columns indicate significant differences between crayfish density.

Fig. 2 Mean number of trapped crayfish, (mean \pm SE) in a patch invaded or not by Ludwigia grandiflora (2a), and according to the interaction "presence of L. grandiflora - maturity stage of crayfish" (2b). Statistical differences (Tukey's test, $\mathrm{p}<0.05$ ) are indicated: different small letters above columns indicate significant differences between treatments. 
Fig. 1
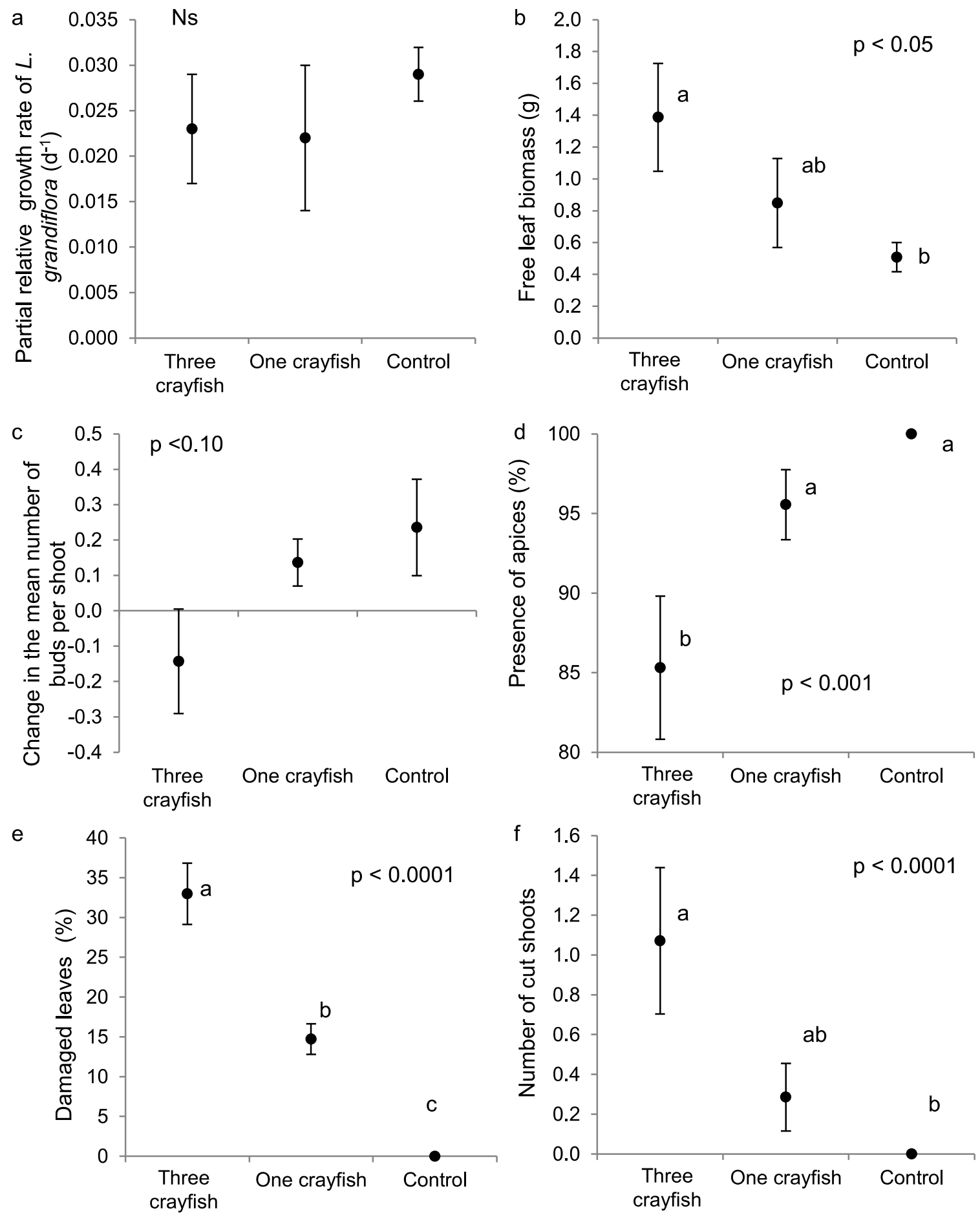

Crayfish treatments

Crayfish treatments 
Fig. 2.

a

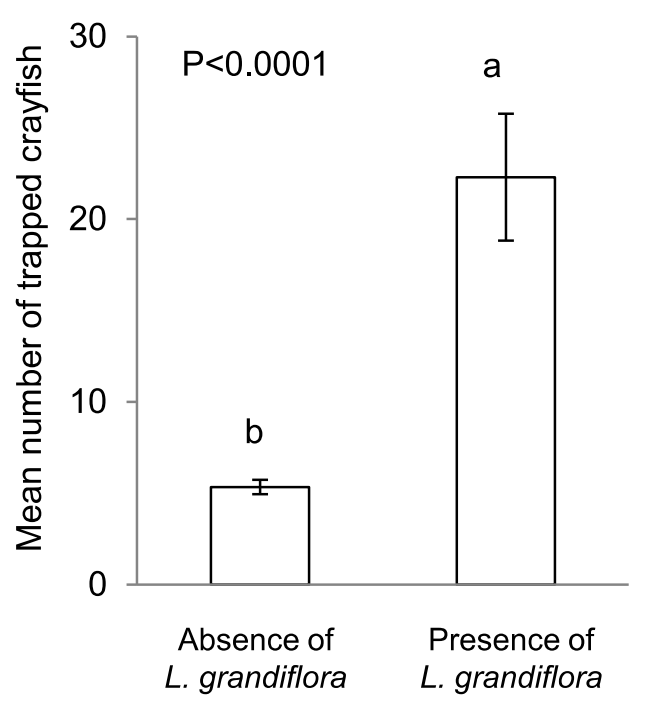

b

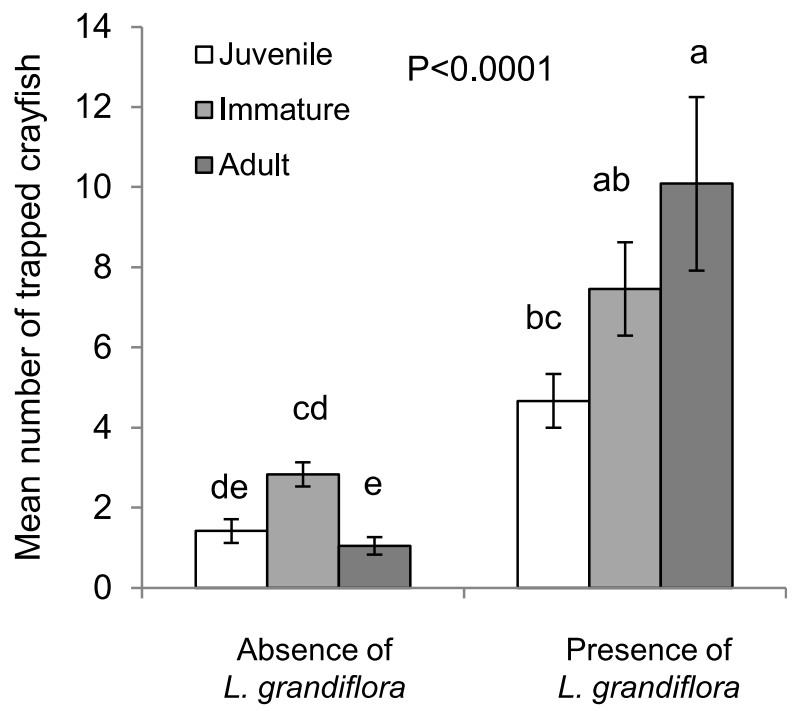

